\title{
Health Education Influence the Maybrat's Women Early Cancer Cervical Detection
}

\author{
Yowel Kambu ${ }^{1}$, Simon Lukas Momot ${ }^{1}$ \\ ${ }^{1}$ The Lectures of nursing department of Polytechnic Health Ministry of Sorong, 98417, Papua Barat, Indonesia.
}

\begin{abstract}
Until now, cervical cancer is still as the leading cause of the death of women worldwide. WHO was estimates that cancer cases will rises sharply until 2030. Although the cervical cancer data of West Papua is the lowest $0.1 \%$ in Indonesia, especially in Sorong Raya region certainly wasn't have the real data, but the iceberg phenomenon is still continues to occur. The study aim was to determine the effect of health education toward the early detection action of cervical cancer by the Maybrat's Women. The research method used was quasiexperimental with one group pretest posttest approach using non-probability puposive sampling technique. From the 30 participants were recruited based on inclusion criteria through the paired $t$ test defined that there was an influence of health education toward early cervical cancer prevention action by Maybrat's Women at Maybrat ( $p=0.011, \alpha<0.05$ ). Health promotion of cervical cancer in Maybrat Regency should be strengthen by the adequately funding encouragrment.
\end{abstract}

Keywords: health education, early detection, cervical cancer.

\section{Introduction}

World Health Organization (WHO) estimates that cancer deaths were 7 million people worldwide, people suffering from cancer were 25 million, but it will increase sharply by the 2030. meanwhile in Indonesia alone, cervical cancer was the first killer, every 30 minutes 1 person dies and every 15 minutes there was 1 new case ${ }^{1}$. Those means that, people who died from cancer increased by $200 \%$ and those living with cancer by $300 \%{ }^{2}$. The Indonesian Ministry of Health (2014) also reported that cervical cancer was the highest case in all hospitals were $12.8 \%$. Even more worrying is that the data shows is only an iceberg phenomenon, where only very few cases have been detected in hospitals compared to communities that have not ${ }^{3}$.

Even so, it turns out the Riskesdas rerearch results showed that the prevalence of cervical cancer in the provinces of Gorontalo and West Papua was the lowest at $0.2 \%$ (508 cases) and $0.1 \%$ (222 cases) when compared to other 31 provinces, even in Papua province $1.1 \%$ $(3,642 \text { cases })^{2}$. Likewise with the Sorong Raya region in general, there were no definitive data on cervical cancer cases. Data from the Sorong District General Hospital shows a referral hospital from other districts in the vicinity, the number of cervical cancer patients who has come for the treatment purpose since 20132015 were estimated to be only 1-3 cases and there were no new cases. Based on the National Health Indicator Survey (Sirkesnas) (on May 2016), data obtained from the Maybrat District Health Office in 2014-2015, there were an increases in the number of Fertile Women (WUS) ages 15-49 years from 11,428 to 13,600 people (total population of 45,170 people) ${ }^{4}$. However, from the results of a survey of the actions of Maybrat Women in preventing cervical cancer, no Maybrat Woman was found who had made early detection of cervical cancer.

This has actually become a concern, considering that one of the risky behaviors (sexual transmitted disease) which is a medium of transmission of high risk of human papillomavirus (high risk HPV) that causes cervical cancer $^{3,5}$ tends to be high in the West Papua region especially Maybrat. In addition, if it is seen that those ages of women at risk of cervical cancer ranges from 2050 which is a productive age in terms of reproductive, economic and social social physiological functions will be disrupted.

One of the factors causing the detection of cervical 
cancer cases is the lack of knowledge of women about the dangers of cervical cancer that have an impact on the low awareness and actions of Maybrat women to take early detection of cervical cancer ${ }^{3}$. A good knowledge of women about cervical cancer would encourage their actions to take prevent as early as possible ${ }^{6}$. Early recognition of cervical cancer is important because it can reduce new cases with prevention efforts more easily done if the risk factors and symptoms of cancer were identified ${ }^{7}$.

\section{Material and Method}

Research method used is quasi experiment with one group pre-postest test only design. Purposive sampling technique used to recruit the respondent. The data analysed with $\mathrm{t}_{\text {test }} \mathrm{s}^{8,9}$.

\section{Results}

The following data of table 1 below is an univariate analysis result of the 30 s respondents characteristics of the Maybrat's women.

Table 1. frecuency distributions based on the respondent characteristis.

\begin{tabular}{|c|c|c|}
\hline The Characteristics & Frequency & $\%$ \\
\hline $\begin{array}{ll}\text { Formal Educations } \\
- & \text { none } \\
- & \text { Elementery School } \\
- & \text { Yunior School } \\
- & \text { Senior high School } \\
- & \text { College }\end{array}$ & $\begin{array}{l}3 \\
2 \\
7 \\
14 \\
4 \\
\end{array}$ & $\begin{array}{l}10 \\
6.7 \\
23.3 \\
46.7 \\
13.3 \\
\end{array}$ \\
\hline $\begin{array}{ll}\text { Marital } & \text { Status } \\
- & \text { none } \\
- & \text { Civil Marital } \\
- & \text { Cultural Marital } \\
- & \text { Life divorce } \\
- & \text { An affair }\end{array}$ & $\begin{array}{l}9 \\
13 \\
6 \\
1 \\
1\end{array}$ & $\begin{array}{l}30 \\
43.3 \\
20 \\
3.3 \\
3.3\end{array}$ \\
\hline \begin{tabular}{ll}
\multicolumn{2}{l}{ Number of Couples } \\
- & One \\
- & More then one \\
- & None
\end{tabular} & $\begin{array}{l}18 \\
2 \\
10\end{array}$ & $\begin{array}{l}60 \\
6.7 \\
33.3\end{array}$ \\
\hline $\begin{array}{ll}\text { An Occupational } \\
- & \text { Civil duty } \\
- & \text { Private } \\
- & \text { Parmer } \\
- & \text { Vendor } \\
- & \text { House wife } \\
- & \text { None }\end{array}$ & $\begin{array}{l}1 \\
2 \\
2 \\
3 \\
9 \\
13\end{array}$ & $\begin{array}{l}3.3 \\
6.7 \\
6.7 \\
10 \\
30.3 \\
43.3\end{array}$ \\
\hline \begin{tabular}{ll}
\multicolumn{2}{l}{ Income (IDR) } \\
- & Less than 1 million \\
- & $1-3$ million \\
- & $3-5$ million \\
- & None
\end{tabular} & $\begin{array}{l}13 \\
6 \\
1 \\
10\end{array}$ & $\begin{array}{l}43.3 \\
20 \\
3.3 \\
33.3\end{array}$ \\
\hline
\end{tabular}


Notes: From the table 1. Shown that the bigests proportions are senior high school (46.7\%), civil marital status (43.3\%), lifes couple $1(60 \%)$, non occupation (43.3\%) and income less than 1 million (43.3\%) and the smallests are elementery school $(6.7 \%)$, life divorce status and and anaffair (each of these are 1\%), the number of life couple are more than $1(6.7 \%)$, work as civil duty (3.3\%) and earning 3-5 million (3.3\%).

The table 2 follows describe the distribution of mean values and standard deviations and minimum and maximum values based on age of the Maybrat's Women.

Table 2. The distribution based on ages

\begin{tabular}{|l|l|l|l|l|}
\hline Variable & Mean & SD & Min-Max & $\mathbf{9 5 \%}$ CI \\
\hline Ages & 28.43 & 9.33 & $12-44$ & $\begin{array}{l}24.95- \\
31.92\end{array}$ \\
\hline
\end{tabular}

Note: The result analysis shown that the Maybrat's women ages mean values are 28,43 (CI: 24,95-31,92), with the SD 9,33. Youngest and oldest are 12 and 44. From the interval results could be concluded that $95 \%$ which means it is believed that the average ages of a Maybrat's women are between 24.95 to 31.92 years.

Hypothesis test results with paired t test in table 3 below to test the significance of the mean value, standard deviation, standard error and probability values before and after health education intervention.

Table 3. The mean distribution values of cervical cancer early detection preventian.

\begin{tabular}{|c|c|c|c|c|c|}
\hline $\begin{array}{l}\text { Prevention } \\
\text { Knowledge }\end{array}$ & Mean & SD & SE & $\begin{array}{l}\mathbf{p} \\
\text { value }\end{array}$ & $\mathbf{n}$ \\
\hline Before & 64.83 & 11.706 & 2.137 & \multirow{2}{*}{0.011} & \\
\hline After & 70.83 & 10.992 & 2.007 & & \\
\hline
\end{tabular}

Notes: the knowledge mean average after intervention is 70,83 with the SD 10,992. It shown that the mean value differentiation is 10 with the SD $-1,643$. The paired $t$ test results shows that the $p$ value equal 0,011 , means there is an effect of health education toward the cervixal cancer early detection action of Maybrat Women.

\section{Discussions}

The scope of respondent conducted is carried out at the working area of Ayamaru Public Health Center of Maybrat Regency with a purposive sampling technique, the sample that took in accordance with the research objectives and inclusion criteria.

The study results shows that there was a significant influence between health education on knowledge of preventive measures for early detection of cervical cancer, which indicated that health education through health promotion efforts is important to increase selfawareness of Maybrat's women's self-awareness about the dangers of cervical cancer so that they would motivated to take early cancer detection measures trough the Cervix screenings are both by IVA method and/or pap smear.

Although the May 2016 Sirkesnas data conducted in the Kocuas village showed that Maybrat women in the village had not been exposed to knowledge of preventing early cervical cancer detection, but data from the Kambuaya public health services center revealed by health NGO practitioners Dr. Sraun shows that health promotion and early detection of cervical cancer IVA method and breast cancer were always carried out in other Maybrat regions with \pm 63 Maybrat women have been netted undergoing cervical cancer early detection tests in 2015-2016 as follows: Mare village 40 people, Away village 5 people (found 2 suspects), Kamrou Aitinyo village 5 people, Aifat 4 village, Temel village (Ayamaru Jaya) 5 people and Mapura village 4 people (November 2016). Meanwhile, for the East and West Aifat regions (including the Kocuas \& Kocuwer villages) there are no Maybrat women who have been netted for early cervical cancer detection. One of the factors that caused it is the "stigma" that is still inherent in the community and husbands who reject their wives which causes people to still be ashamed and avoid not checking their cervical cancer status. This is in line with research by Marván, Ehrenzweig \& Catillo-López about knowledge about cervical cancer prevention and psychosocial barriers to cervical cancer testing in 384 Mexican women found that although the majority of Mexican women (80\%) had received pap smear information in 3 in the last year, however, only $29 \%$ had performed pap smears according to the Noma of Mexico 
which indicates inadequate knowledge of Mexican women about risk factors for cervical cancer specifically for women with low education, disrespect for citizens and opinion that pap is an embarrassing examination so that their husbands does not allow his wive to follow the pap examinations ${ }^{10-12}$.

This is certainly a serious concern to the local government, specifically related agencies, namely the health department to be able to promote health promotion programs and monitor the performance of 14 public health centers in the Maybrat district government area.

\section{Conclusion}

There is an effect of health education toward the cervical cancer prevention action by the Maybrat's Women at Maybrat Regency.

\section{Disclaimer Statement}

Acknowledgment The authors acknowledge Head of the Ayamaru's Public Health Service Center who has facilitated this research.

Funding Source This research was funded by the Sorong Health Polytechnic institution.

Conflicts of Interest No conflict of interest were complained by those who involved in this research.

Ethical Clearence It has been allready approved by the Sorong Health Polytechnic ethical clearence committee.

\section{References}

1. Nugraha. Boyke. D. Pembunuh Nomor Satu Adalah Kanker Serviks. In: The Seminar Result was Published on Jaya TV (Internet) 2013 May 13; (cited 2016 June 10). available from https://www. youtube.com/watch? $\mathrm{v}=\mathrm{X} 2 \mathrm{UgZ6eRAwQ}$

2. Riskesdas. Data Riskesdas \& Target Data Penduduk Kemenkes. Jakarta: Balai Litbang Kemenkes RI; 2013 (cited 2016 June 10). Available from www. depkes.go.id

3. Manafe, D.. Hari Kanker Sedunia: Di Indonesia, Kasus Kanker Payudara dan Serviks Tertinggi; 2014 February 05 (Retrieved 2015 June 24). Availabe from Fight Against Breast Cancer: http://www. beritasatu.com/kesehatan/164592-di-indonesia- kasus-kanker-payudara-dan-serviks-tertinggi.html. 2014.

4. Sirkesnas. Survei Indikator Kesehatan Nasional Laboratorium Manajemen Data; 2016 (cited 2016 June 10). Jakarta: Kementerian Kesehatan RI. Available from labdata.litbang.depkes.go.id/risetbadan-litbangkes/menu-riskesnas/menu-rikus/422sirk-2.

5. Noviana, H. Human Papiloma Virus dan kanker serviks; (cited 2015 June 23). Available from http:// www.kalbemed.com/Portals/6/26_189PraktisHuman \% 20 Papillomavirus $\% 20$ dan $\% 20$ kanker\%20Serviks.pdf.

6. Mirayashi, D., Raharjo, W., \& Wicaksono, A. Hubungan antara tingkat pengetahuan tentang kanker serviks dan keikutsertaan melakukan pemeriksaan inspeksi visual asetat di Puskesmas Alianyang Pontianak (Internet)). Jurnal Mahasiswa PSPD FK Universitas Tanjungpura $2014 ; 1(1)$ : 1-18. Available from: http://jurnal.untan.ac.id/ index.php/jfk/article/view/7830

7. Informasi, P. D. Situasi Penyakit Kanker. In P. D. Informasi, (internet); Buletin Jendela Data dan Informasi Kesehatan Buletin Jendela Data dan Informasi Kesehatan. 2015 (cited 2016 June 10) Vol.1: p. 1. Jakarta: Kementerian Kesehatan RI. Available from https://www.depkes.go.id/ download.php? file=download/pusdatin/buletin/ buletin-kanker.pdf

8. Dahlah, M.S. Statistik untuk Kedokteran dan Kesehatan. Edisi 4. Jakarta: Salemba Medika; 2009. P.1-28

9. Hastono, Sutanto.P. Analisa Data Kesehatan (Basic Data Analysis for Health Research Training. Depok; FKM UI; 2007

10. Marván, M. L., Ehrenzweig, Y., \& Catillo-López, R. L. Knowledge about cervical cancer prevention and psychosocial barriers to screening among Mexican women (Internet). 2013 Journal Of Psychosomatic Obstetrics And Gynaecology, 2013; 34(4), 163-169. Available from doi:10.3109/01674 82X.2013.846904.

11. Rosmala Nur, Anwar Mallongi, Indah P. Kiyai Demak, Fadliah, Elli B. Yane, Nurhaya S. Patui, Marselina , H. Muhammad Rusydi, Muhammad Asep Dwitama and R. Erina Thursina, Early-Age Marriage and the Impact of Health Reproduction Women. Journal of Engineering and Applied 
Sciences, 2019; 14: 981-986.

12. Rosmala Nur, Nikmah Utami Dewi, Khairunnisa and Anwar Mallongi, Golden standard feeding and the risk of 25-60 month-old underweight children in Central Sulawesi, Indonesia. Asian J. Clin. Nutr., 2017; 9: 104-110. 